\title{
Nuclear viewpoint in India
}

\author{
Anshu Bharadwaj, Lakshminarayana Venkat Krishnan and \\ Subramaniam Rajagopal, Center for Study of Science, Technology \\ and Policy (CSTEP), Bangalore-560094, Karnataka, India \\ Address all correspondence to Anshu Bharadwaj at anshu@cstep.in \\ (Received 7 December 2016; accepted 5 May 2017)
}

\section{ABSTRACT}

\section{Nuclear power is a crucial source of clean energy for India. In the near-term, India is focusing on thermal reactors using natural and enriched uranium. In the long-term, India is exploring various options to use its large thorium reserves.}

India's present nuclear installed capacity is $5680 \mathrm{MW}$, which contributes to about $3.4 \%$ of the annual electricity generation. However, nuclear power is an important source of energy in India's aspirations for energy security and also in achieving its Intended Nationally Determined Contributions (INDC), of 40\% fossil free electricity, by 2030. India has limited uranium reserves, but abundant thorium reserves. The Nuclear Suppliers Group (NSG) lifted restrictions on trade with India, in 2008, enabling India to import uranium (natural and enriched) and nuclear reactors. In the near-term (2030), the nuclear capacity could increase to about 42,000 MW. This would be from a combination of domestic Pressurized Heavy Water Reactors (PHWR) and imported Pressurized Water Reactors (PWR). For the long-term (2050), India is exploring various options for utilising its vast thorium reserves. This includes Advanced Heavy Water Reactor and Molten Salt Breeder Reactor. However, generating public acceptance will be crucial to the expansion of the nuclear power program.

Keywords: nuclear materials; U; energy generation

\section{DISCUSSION POINTS}

- Why is nuclear power important for countries such as India, which have large energy demand?

- What is the role of alternative power cycles for using thorium?

- How can public acceptance be generated in the safety aspects of nuclear power?

\section{Introduction}

India has an electricity generation capacity of 310,005 MW as on December 31, 2016. Of this, coal contributes 188,967 MW and nuclear power $5680 \mathrm{MW}$ (Fig. 1). ${ }^{*}, 1$ The total electricity generation was 1159 billion $\mathrm{kWh}$ in 2016-17. ${ }^{2}$ Nuclear power contributes to $3 \%$ of the total electricity generated. ${ }^{3}$

Despite its large generation capacity, India's per capita electricity consumption is about $900 \mathrm{kWh}$, well below the world average of $3030 \mathrm{kWh} .{ }^{4}$ Further, nearly $40 \%$ of the population still lacks access to electricity. To address these concerns, the Indian government has set ambitious electricity capacity addition targets, to ensure $24 \times 7$ supply, to all its citizens, especially those living in rural areas. The electricity generation capacity is expected to reach nearly 800,000 MW by $2030.5,6$
In the Paris Climate Change Agreement, India announced its Nationally Determined Contributions (NDC), which include a commitment to develop $40 \%$ of generation capacity from fossilfree sources by 2030 (hydro, nuclear, solar, wind, and biomass). ${ }^{7}$ Therefore, fossil-free sources could contribute at least 300,000 MW of the generation capacity by 2030 . India has already announced a renewable energy target of 175,000 MW by 2022 (solar $100,000 \mathrm{MW}$, wind 60,000 MW). Since solar and wind have almost achieved grid parity, there is a good possibility of achieving this target. Moreover, the renewable capacity could further increase to about 250,000 MW by 2030. Regarding nuclear power, the NDC mentions an aspiration of $63,000 \mathrm{MW}$ by 2030 . As per government estimates, based on the ongoing projects, the capacity could increase to 14,850 MW by $2020-21$ and 27,480 MW by $2023-24 .^{8}$ The Indian Prime Minister called to triple India's present nuclear capacity by $2023-24 .{ }^{9}$ However, it appears that these projections are below the NDC aspiration of 63,000 MW. In a later section, we attempt an assessment of likely capacity addition by 2030 .

\section{Why nuclear power?}

It is clear from the above section that, at present, nuclear contributes a small share to India's electricity generation. Further, even by 2030 , nuclear power would still contribute only a small share of the installed capacity. This brings us to the question: Why is nuclear power important for India? There are three main reasons. 


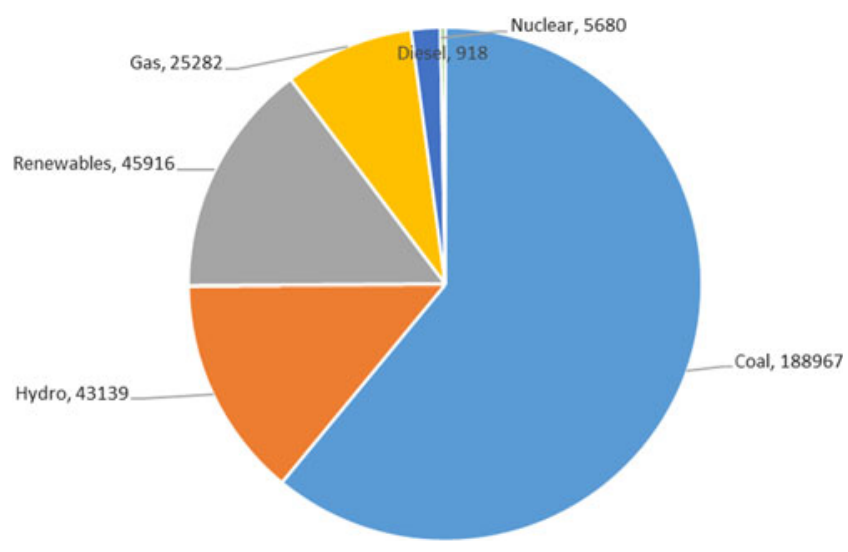

Figure 1. India's installed electricity generation capacity (MW) (Data from Central Electricity Authority, India ${ }^{1}$ ).

First, for a country facing a huge energy challenge, every $\mathrm{kWh}$ is important, whether generated or saved. For instance, 30,000 MW of nuclear capacity is a significant contribution in absolute terms, and is equivalent to $110,000 \mathrm{MW}$ of solar-based capacity in energy generation. ${ }^{\dagger}$ Second, India is targeting large renewable solar and wind generation, which suffer from the problem of intermittency. Hence, there is a need for base-load power to help manage the intermittent generation and nuclear power is a source of clean base-load electricity. Finally, in the long-term scenario (2050 and beyond), nuclear power could contribute a much higher share of electricity. Therefore, it is in India's interest to have a robust nuclear power program, in view of long-term energy security.

The Indian nuclear power program was developed in the 1950s and is commonly known as the Three Stage Program. ${ }^{10}$ India was not in a position to import nuclear fuel, reactor or technology as it is not a signatory to the Nuclear Non-Proliferation Treaty (NPT). Therefore, the Three Stage Program was an entirely indigenous program. It was based on the rationale that India had limited uranium reserves (61,000 tonnes), which constitute about $2 \%$ of the global reserves. In recent years, ongoing countrywide exploration activities have led to an increase in estimates of domestic uranium reserves. For instance, Tummalapalle deposit alone is believed to have about 60,000 tonnes of uranium ${ }^{11}$ and mining activities have commenced there. Similarly, new reserves have been discovered in other locations as well. Therefore, present uranium reserves are almost double of earlier estimates, when the Three Phase program was envisaged.

India has abundant thorium, nearly $25 \%$ of the global deposits. Therefore, the Three Stage Program had a long-term objective of utilising thorium for achieving energy security. The three stages of the Program are:

Stage 1: Build Pressurised Heavy Water Reactors (PHWRs) using domestic natural uranium $\left(\mathrm{U}^{235}\right)$. Reprocess the spent fuel to recover plutonium $\left(\mathrm{Pu}^{239}\right)$ for use in Stage 2. The original estimate of domestic uranium reserves could support $10,000 \mathrm{MW}$ of PHWRs for 40 years. The new estimates (including Tummalapalle and other reserves) can potentially help build an additional 10,000 MW of PHWRs.
Stage 2: Build Fast Breeder Reactors (FBR), using the depleted uranium in spent fuel from PHWRs and separated Plutonium. The objective is to design metal fueled reactors, which have the potential for doubling time of as low as six years. ${ }^{12}$ Addition of Thorium $\left(\mathrm{Th}^{232}\right)$ in the blanket of FBRs would generate $\mathrm{U}^{233}$ for use in later reactors.

Stage 3: Build thorium-based reactors using $\mathrm{U}^{233}$ and $\mathrm{Th}^{232}$.

India's nuclear landscape was transformed by a series of developments starting in 2008. India signed an agreement with IAEA for safeguards of civilian nuclear facilities that included commitment to an additional protocol and led to a waiver by the Nuclear Suppliers Group (NSG). This allowed the supply of trigger list items to India for such facilities. ${ }^{13}$ Subsequently, India signed the nuclear cooperation agreement with the US. In 2016 , the Indo-Japan civil nuclear cooperation agreement was signed. It is sufficiently wide ranging in its scope of nuclear science and technology and enables the import of nuclear reactors from the US with Japanese components. Together these have freed India from the earlier restrictions in import of nuclear fuel, reactors and technologies opening up several future capacity addition scenarios, in addition to those envisaged under the Three Stage Program.

For instance, India has the option to import uranium and build more PHWRs. It can also import Pressurised Water Reactors (PWRs), which are based on enriched uranium, for faster capacity addition in the near future. There is also scope for introduction of thorium in PWRs. Another possibility is to introduce slightly enriched uranium in PHWRs, to enable higher burn-up, or allow the use of thorium. A further possibility is the design of a reactor, specifically for thorium utilisation, using Low Enriched Uranium (LEU) or plutonium, as in the Advanced Heavy Water Reactor (AHWR). Therefore, India's future nuclear landscape would be different from what was originally planned under the Three Stage Program.

\section{Objective}

This article seeks to examine the prevailing viewpoint regarding nuclear power development in India. It explores various scenarios for nuclear power growth in the near-term (2030) and also in the long-term (2050). The article discusses the present thinking regarding the following:

\section{Technology and reactor choices}

At present, India is focusing on adding capacity through a combination of PHWR and PWR. These would be relevant in achieving capacity addition in the immediate future (2030). However, India continues to pursue the FBR option, which is a crucial bridge to the eventual long-term thorium utilisation plans. The article will comment on the advanced-cycle options under consideration for early thorium utilisation.

\section{Economics and resource requirements}

The article discusses economics of the prevailing reactor options, PHWR and PWR. It is premature to talk about the economics of advanced cycles. It also discusses the land and fuel requirements for operating the existing and future reactors. 


\section{Public acceptance}

Nuclear power is always associated with public concern about the safety of reactors. It is important to establish transparent regulatory procedures to convince the public about the safety of plant design and operation. The article will discuss their status and thinking in this regard.

\section{Technology and reactor choice}

India commenced the commercial operation of its civil nuclear power program, in 1969, by commissioning two medium-power Boiling Water Reactors (BWRs), as a turnkey project, with financial assistance from the US. These plants were designed by GE and located in Tarapur (Maharashtra). It then built two PHWRs in Rajasthan, with Canadian assistance, for well thought out reasons of ease of indigenisation of technology and fuel. The collaboration with Canada ended in 1974, consequent to a nuclear test conducted by India. This provided motivation for India to strengthen its nuclear infrastructure and build PHWRs on its own. The designed power of these early reactors was about $200 \mathrm{MW}$ and this fit in well with the small grids that prevailed at the time. They were followed by upgraded designs of $540 \mathrm{MWe}$ first and 700 MWe subsequently. India also accepted a Russian offer to build VVER (Water-Water Energetic Reactor) type PWR and has built two reactors of 1000 MW. With this background, this section examines two scenarios: Near term (2030) and long term (2050).

\section{Near-term scenario (2030)}

At present, 20 reactors, from three categories of reactor systems, are operating, with a cumulative installed capacity of 5680 MW (Table 1).

These reactors operate at high Capacity Utilisation Factors (CUFs) and contribute about $3 \%$ electricity to the grid. India's main interest lies in recycling the plutonium contained in spent fuel from the PHWRs, to make fuller use of the meagre indigenous uranium resources. A Fast Breeder Test Reactor (FTBR), designed with French assistance, has been operating since 1985. Initially it was fueled with a mixture of carbides of uranium and plutonium. Currently, it operates on a mixture of the oxides. Fuels, of both types, are fabricated indigenously.
Further, 8 reactors (cumulative capacity of $6300 \mathrm{MW}$ ) are currently under various stages of construction (Table 2 ). When completed, they will raise the total nuclear capacity to about 12,000 MW.

It is evident from the tables provided above that PHWRs presently constitute the bulk of India's present nuclear generation capacity. These have been the main workhorse of Indian nuclear power industry, with 17 operating reactors and 4 under construction. Though initial difficulties in heavy water production led to delays in the commissioning of first few reactors, adequate heavy water stock to provide for current and future units now exists. In fact, some of the PHWRs have reached capacity factors of $90 \%$ and above. One of the units in Rajasthan recorded $94.4 \%$ and was operated for 765 days at a stretch.

Indian industries have actively participated in the indigenous manufacture of major components and design standardisation to facilitate short construction times. Therefore, PHWRs have a well-established manufacturing supply chain in the country.

As explained in the previous section, the NSG waiver has now opened up the possibility to import natural uranium. Therefore, there is a strong case for India to expand the PHWRs program beyond the 10,000 MW as originally envisaged in the Three Phase program. New PHWRs can be based on both domestic and imported natural uranium. India will also have the opportunity to develop reactors of higher capacity (1000 MW and above) to ensure more power is generated at a given site.

The NSG waiver also permits India to build PWR reactors. Already, Russian, French and American firms have expressed interest to build a large number of PWRs. New sites have been identified to build the imported PWRs and Indian firms are preparing themselves to manufacture systems and components for these. For instance, indigenous manufacture of major equipment is expected to cover $45 \%$ of the cost in third and fourth units at Kudankulam, which are based on Russian VVER design and are presently under construction. ${ }^{14}$ Therefore, there is a good case to build more Russian reactors (VVERs). As of now, two reactors have been completed in Kundankulam, and two more are under construction. A new set of reactors of higher power (1200 MW) are now being proposed. Moreover, Russian

Table 1. Present nuclear installed capacity.

\begin{tabular}{l|c|c|c} 
Reactor type & Number of reactors & Sites & Tapacity (MW) \\
\hline Boiling water reactor (BWR) & 2 & Tarar & 320 \\
\hline Pressurised heavy water reactor (PHWR) & 17 & $\begin{array}{c}\text { Tarapur, Rajasthan, Kalpakkam, } \\
\text { Narora, Kakrapar, Kaiga }\end{array}$ & 4360 \\
\hline Pressurised water reactor (PWR) & 1 & Kudankulam & 1000 \\
\hline Total & 20 & 7 & 5680 \\
\hline
\end{tabular}


Table 2. Nuclear reactors under construction.

\begin{tabular}{l|c|c|c}
\hline \multicolumn{1}{l}{ Reactor type } & Number of reactors & \multicolumn{2}{c}{ Sites } \\
\hline Pressurised heavy water reactor (PHWR) & 4 & Rajthan, Kakrapar & 2800 \\
\hline Pressurised water reactor (PWR) & 3 & Kudankulam & 3000 \\
\hline Fast breeder reactor (FBR) & 1 & Kalpakkam & 500 \\
\hline Total & 8 & 4 & 6300 \\
\hline
\end{tabular}

government is providing a state loan for construction of these projects. Thus, there is a good opportunity to build more Russian VVERs beyond the present plans.

There are reports that India is exploring the possibility of indigenously developing a 900 MW PWR plant. ${ }^{15}$ Therefore, India's current plans consist of building a large number of PWRs that could include a prototype of indigenous design as well.

Grover $^{16}$ provides a comprehensive future plan to build new nuclear reactors (Table 3). This includes PHWRs, PWRs from five different reactor systems, and also FBRs.

We now make an assessment of how many of these reactors (mentioned in Table 3 ) could be completed by 2030 . This would require timely steps for regulatory, environmental and safety clearances, besides contractual negotiations on unit energy costs. Most of the above mentioned reactors are presently in different stages of development. In most cases, technical and commercial agreements are still being negotiated, while in other cases, regulatory approvals are under process.
It appears that the capacity addition in the time frame of 2030 will largely come from the indigenous PHWRs and the Russian VVER reactors. We base our assessment on the assumption that it generally takes 6-7 years to commission a twin reactor complex after the first pour of concrete. The Government has given 'in principle approval' for sixteen PHWRs. Out of these, fourteen reactors are at new sites: Chutka (2 units) and Bhimpur (4 units) in Madhya Pradesh, Gorakhpur in Haryana (4 units) and Mahi-Banswara in Rajasthan (4 units). Two more reactors are proposed to be built at the existing Kaiga site. We feel it is possible to complete these sixteen reactors by 2030 as there is an established indigenous manufacturing supply chain and experience in building PHWRs. Thus, PHWRs can add another 11,200 MW of capacity by 2030 .

Regarding the PWRs, as mentioned earlier, there is a strong case to build more of Russian design VVERs. Two (1000 MW each) are presently under construction and two more can be completed at the same site. There are plans to build six more VVERs of larger capacity (1200 MW each). Considering that

Table 3. Future plan for building new nuclear reactors.

\begin{tabular}{|c|c|c|}
\hline Reactor type & Number of reactors & Capacity (MWe gross) \\
\hline Pressurised heavy water reactor (PHWR) $700 \mathrm{MW}$ & $16^{* *}$ & 11,200 \\
\hline \multicolumn{3}{|l|}{ Pressurised water reactor (PWR) } \\
\hline - VVER (Russian design, 1000 MW) & $2^{\dagger \dagger}$ & 2000 \\
\hline - VVER (Russian design, 1200 MW) & 6 & 7200 \\
\hline - Westinghouse design (1100 MW) & 6 & 6600 \\
\hline - BWR (GE design, 1594 MW) & 6 & 9564 \\
\hline • EPR (French design, 1650 MW) & 6 & 9900 \\
\hline Fast breeder reactor (FBR)—600 MW & 6 & 3600 \\
\hline Total & 52 & \\
\hline
\end{tabular}


it takes 6-7 years to build a twin reactor complex, we expect that four such reactors could be completed by 2030 . Similarly, we expect four Westinghouse reactors (1100 MW each) and four French EPRs (1650 MW each) to be built by 2030. Of course, it depends on expeditious completion of regulatory approvals and contractual agreements. Considering all these, it is reasonable to expect PWRs to add about $18,000 \mathrm{MW}$ by 2030.

Regarding FBRs, the future construction depends on the experience with the present FBR and also availability of plutonium fuel. We assume that it should be possible to construct two more FBRs by 2030 .

Taking into account all the above, we feel that about $30,000 \mathrm{MW}$ of new nuclear reactors can be built by 2030 . This will increase the nuclear installed capacity to 42,000 (including present reactors and those under construction).

Though the past record in the country suggests otherwise, the addition of 30 reactors in 13 years may be doable, judging from the experience of other countries such as France and China $^{17}$ (Figs. 2(a) and 2(b)).

Following the oil shock of the early 1970 s, France succeeded in beginning the building of 53 reactors, of 3 types, in 19 sites, during a 14 year period (1971-85). They were commissioned between 1977 and 1993. Later, China was successful in starting construction of 33 reactors, of 5 types, in 10 sites, in 16 years, between 1996 and 2012 and these began operations between
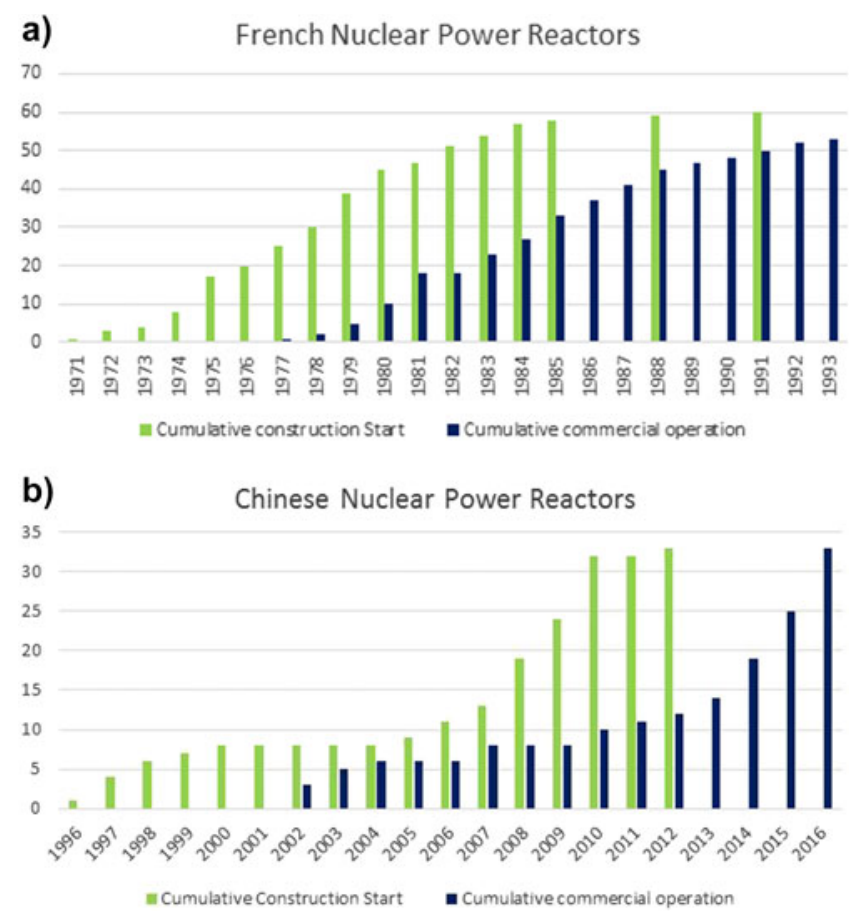

Figure 2. Historical rapid build-up of nuclear power capacity in France (a) and China (b) based on data provided in IAEA Power Reactor Information System website (https://www.iaea.org/PRIS/ CountryStatistics/CountryStatisticsLandingPage.aspx).
2002 and 2016. In both cases, the progress was slow in the initial 4-5 years but accelerated thereafter.

Seven sites for new reactor units in India have been identified and site preparations have been underway in some. The designs of these reactors are not new and their safety has been assessed by Regulatory bodies in other countries. Similar reactor units are under construction elsewhere. In the event of uncertainties in proceeding with AP1000 units as a result of the more recent developments, their substitution by VVER1200 is a possibility worth considering.

The worldwide slowdown in additions to the nuclear reactor fleet may facilitate supplies from manufacturers who were expecting new orders. In parallel, Indian industries must be made to gear up for supplementing the procurement. Simultaneously, development of human resource development must receive necessary attention.

\section{Long-term scenario (2050)}

The previous section highlighted that in the near term (2030) almost the entire nuclear capacity would be from a combination of PHWRs and PWRs. In addition, there could be 2-3 FBRs. Clearly, this is important from the point of view of rapid capacity addition to address India's immediate energy needs. However, the longer term interest is in exploiting India's abundant thorium reserves, which is crucial for long-term energy security. As explained in an earlier section, the Fast Breeder option (and plutonium) is a bridge to thorium utilisation. This section discusses the options for early thorium utilisation.

\section{Fast breeder reactor (FBR)}

India has a policy to reprocess the spent fuel of thermal reactors. However, the US has decided to not reprocess spent fuel as current low uranium price does not justify the economics of reprocessing. Hence, the US prefers disposal of spent fuel. India, on the other hand, views plutonium as a source of energy, which is too precious to be buried. Over the years, sufficient spent fuel has been accumulated from the operation of PHWRs. In the coming years, the new PHWRs and PWRs will also generate large quantities of spent fuel. India is allowed to reprocess spent fuel from reactors, which are under international safeguards. The plutonium so recovered can be used to build fast reactors, under international safeguards.

India designed and built the sodium-cooled Fast Breeder Test Reactor (FBTR) in Kalpakkam. This was modeled after the French Rapsodie reactor. The 40 MWt reactor was commissioned in 1985. The indigenously fabricated reactor fuel has performed exceedingly well to date, reaching high burn-up levels of 150,000 MWd/Te. The sodium heated steam generator has also performed well to date. There have been no violent incidents of steam-sodium reactions.

The confidence generated by the success of the FBTR led to the design of a 500 MW Prototype Fast Breeder Reactor (PFBR), fueled by a mixture of uranium and plutonium oxides. The reactor, also located at Kalpakkam, is to be commissioned shortly. 
The fuel is already at site, awaiting loading, after the completion of sodium systems testing. The spent fuel removed from the FBTR has been reprocessed in a laboratory-scale facility. This experience is being used to construct a Fast Reactor Fuel Cycle Facility.

The PFBR has a low breeding ratio of $1.05 .^{18}$ This is suggestive of a simple doubling time of roughly 20 years. Evidently, it will not be able to generate sufficient plutonium for the thorium program. For the next two FBRs being planned, core design modifications are expected to raise the breeding ratio to about 1.2. ${ }^{19}$ Also, Research \& Development (R\&D) is ongoing for developing and testing metallic fuel for future fast reactors, which could have a lower systems doubling time. Similar R\&D activity is in progress for establishing proliferation-resistant non-aqueous pyro-processing of metal fuel to recover plutonium.

India will also need to expand the present reprocessing capacity of about 300 tonnes, which will not be adequate to support the large future FBR program. An integrated nuclear recycle facility capable of handling LWR spent fuel is being designed that can treat 600 tonnes per year. ${ }^{20}$

\section{Options for thorium utilisation}

Over the years, several possibilities for early introduction of thorium in the PHWR systems have been studied. While the reactor physics aspects established feasibility, further progress required adequate quantities of plutonium or enriched uranium. Meanwhile, India has been developing the AHWR. With many novel design features that contribute to better economics and passive safety, this is seen as a Technology Demonstrator.

Engineering and physics test facilities have been set up to validate the design for convincing the Regulatory Body. These include a critical facility for core studies, a 3 MW boiling water loop and a natural circulation loop for studies. ${ }^{21}$ Three versions have been studied with different fuel choices like LEU-thorium, plutonium-thorium, and $\mathrm{U}^{233}$-thorium. The latter two fuel types have also undergone test irradiations in Indian Research and Test Reactors. Thorium bundles loaded in the initial core of some of the PHWRs have been reprocessed to recover $\mathrm{U}^{233}$. Irradiation of MOX assembly containing $\mathrm{U}^{233}$ is ongoing in the FBTR.

While there is potential for early demonstration of the AHWR, the Molten Salt Breeder Reactor (MSBR) is another attractive option in the longer term. This is because of the high temperature, low pressure characteristics of MSBRs. The MSBR also has better safety characteristics and is not prone to major accidents such as those in TMI, Chernobyl, or Fukushima since the fuel is a molten salt. The online reprocessing version of an MSBR requires minimum fissile inventory (less than 1 tonne) and has a breeding ratio comparable to that of an oxide fueled FBR based on sodium cooling. Further, it is capable of power level changes to follow grid requirements, unlike other reactor designs. Nevertheless, it requires a breakthrough in the development of suitable structural materials for this option to be successful.

The Indian situation, with a modest starting fissile inventory and substantial thorium resources, was examined in a recent publication. ${ }^{22}$ They point out the advantages of the MSBR system for breeding and suggest thorium deployment in present generation reactors like PHWRs and Light Water Reactors (LWRs) until introduction of MSBRs. PHWRs are believed to have an edge over LWRs in this context because of flexibility in fuel management. In either case, aspects of fuel design and reprocessing of spent fuel warrant detailed study. Work is on hand for establishing plant scale processing of thoria bundles loaded in PHWRs to recover fissile material. ${ }^{23}$ Accumulation of enough $U^{233}$ can subsequently pave the way for AHWRs.

In the longer term, over the next two decades, several firstgeneration reactors would be permanently shut down and prepared for decommissioning. FBRs could then begin making a contribution. If $R \& D$ in MSBRs matures, a prototype may be built.

The options mentioned above will help expedite thorium utilisation for power generation. However, large-scale thoriumbased power generation still looks to be at least 4-5 decades away. This has also been acknowledged by the Department of Atomic Energy. ${ }^{24}$ At this point, it would be premature to speculate on the thorium-based capacity that can be added-there are still too many unknowns in technology and cost.

\section{Economics and resource requirements}

India has acquired considerable experience in the design and development of PHWRs. Most of the major components have been indigenised and there is a robust supply chain. The cost of setting up two 700 MWe PHWRs, at the Green-Field site in Gorakhpur, was estimated (in 2012) at Rs 235 billion or $\$ 4.5$ billion, at the prevailing exchange rates. It amounts to $\$ 3200 / \mathrm{kW} .{ }^{25}$ This is comparable to other types of reactors.

As of now, the initial investments required for building these reactors are fully met by equity from the Nuclear Power Corporation of India Ltd. (NPCIL). However, in an effort to accelerate construction, NPGIL has established joint ventures with other public sector undertakings to raise equity capital. The Parliament passed a Bill to permit such joint ventures to accelerate nuclear power projects. If these take off without further delay, the prospect of meeting the Government's targets on time would improve considerably.

There is less clarity on the capital cost of PWRs. As of now, India has commissioned two PWRs, which were built by Russian government firms. These projects were supported by a State loan from Russia. The first two 1000 MW PWRs in Kudankulam had an initial sanctioned cost of US $\$ 3.13$ billion $(\$ 1565 / \mathrm{kW}) .{ }^{26}$ The sanctioned cost for two new PWRs at the same site has nearly doubled to US $\$ 3130 / \mathrm{kW} .{ }^{27}$

In addition, Indian government is negotiating with leading US and French companies for building more PWRs at new sites. There is, however, inadequate clarity on the cost of these reactors as not much information is available in the public domain. EDF (France) has proposed to build six reactors (each of $1650 \mathrm{MW}$ ) at Jaitapur. Based on newspaper reports, there are attempts to reach a price of $\$ 4$ billion per reactor, or about $\$ 2500 / \mathrm{kW}$, through greater degree of participation by Indian

6 - MRS ENERGY \& SUSTAINABILITY // VOLUME 4 // e 7 // www.mrs.org/energy-sustainability-journal 
industries in its construction. ${ }^{28}$ The proposal is presently under negotiation with the government and EDF is hopeful of cost reduction through indigenisation. It is said to be possible to indigenise components to the extent of $20-30 \%$ for the first two units and $60-70 \%$ for the fifth and sixth. ${ }^{29}$ It was earlier indicated that France would provide a 25-year loan for the project at $4.8 \%$ interest. It was agreed then that the cost of power from these reactors would be pegged at Rs 6 per unit.

Westinghouse has proposed to build six reactors (AP $1000 \mathrm{MW})$ and there are reports that India has approached the US Exim Bank, which in turn is exploring the possibility of a loan from South Korean export credit agency, since some of the components would be supplied by South Korea. ${ }^{30}$ An agreement on the cost of power is yet to be arrived at.

\section{Fuel requirements}

A significant contribution of the NSG waiver is that it allows India to import uranium. An India Specific Safeguards Agreement (ISSA) signed with the IAEA facilitated agreements with the US and nine other uranium-producing countries, including Russia, France, Kazakhstan, Canada, and Australia. ${ }^{15}$ The domestic PHWRs were operating well, but at low capacity factors owing to inadequate fuel supply. With import of uranium from external sources, the capacity factor of the PHWRs has gradually increased to above $80 \%$.

Table 4 provides the fuel requirements of various types of reactors under operation. The indigenous uranium produced is normally consumed by PHWRs that are outside international safeguards. These reactors require about 350 tonnes of uranium per annum. The remaining PHWRs, which are under international safeguards, require about 325 tonnes per annum. India imported about 3450 tonnes of natural uranium during 2008-2015.

Table 4. Fuel (natural uranium) requirements of various reactors. ${ }^{\ddagger \ddagger}$

\begin{tabular}{l|c|c}
\multicolumn{1}{l}{ Reactor type } & \multicolumn{1}{c}{ Gross power MW } & $\begin{array}{c}\text { Natural uranium (tonnes) } \\
\text { per reactor per year }\end{array}$ \\
\hline PHWR & 220 & 45 \\
\hline PHWR & 540 & 100 \\
\hline PHWR & 700 & 125 \\
\hline BWR & 160 & 32 \\
\hline VVER & 1000 & 130 \\
\hline EPR & 1750 & 180 \\
\hline AP1000 & 1200 & 140 \\
\hline FBR & 500 & $1.1($ Pu) and 3.2 (DU) \\
\hline
\end{tabular}

\section{Land requirement}

India has identified several new sites, especially for building the PWRs. However, even if all existing and new sites were fully utilised, it would still fall short of the target indicated in India's Nationally Determined Contribution (NDC). More sites need to be identified. Some of the criteria to be satisfied, for a site to be chosen for a nuclear power station, can be met by providing suitable design features. For instance, seismic issues can be mitigated by appropriate foundations, and radiological criteria can be satisfied by stronger containment. However, population and environmental criteria eventually become the deciding factors.

All countries require an exclusion area to be established around a power station. Most countries define this area by the distance at which the radiation exposure, in the event of a design basis accident, is within a prescribed limit. A shorter exclusion area can be allowed if the Regulator is convinced of the capability of the containment design of limiting exposure. However, in India, the exclusion area must cover a minimum distance of $1 \mathrm{~km}$ from the center of a reactor. Further, this must be satisfied for each reactor in a multi-reactor power station.

Table 5 provides the land requirement for the recently selected Green-Field projects. It can be seen that a site with more reactor units requires less land per MW. Units of larger size are even better. PWRs of larger power enable more power generation per hectare of land. Auxiliary buildings have a small footprint. Indian power stations, for instance, also need land for a township to house the staff, which is generally located beyond $5 \mathrm{~km}$ from the plant site.

Lack of adequate water resources is a particular limitation for inland sites, whereas at coastal sites seawater can be used for condenser cooling, and desalination plants can provide freshwater for the station and the township. Nearly half of the world's nuclear power plants are located in coastal sites. In India, desalination plants are already in operation in Kalpakkam and Kudankulam. However, eight of the fourteen sites are in inland locations. With few perennial rivers or large lakes, the targeted plan will call for more of coastal sites.

\section{The liability factor}

In India, nuclear power plants are designed, built and operated by the Central Government. Therefore, the Government is exclusively liable for providing compensation in the event of an accident. However, with the NSG waiver, foreign suppliers have gained access to building reactors in India. This has brought the civil liability issue to the forefront. As part of the agreement, the US Government required India to adopt internationally accepted provisions that made the plant operator exclusively liable.

The Indian Parliament passed the Civil Liability for Nuclear Damage Act in 2010. One of the clauses provides the operator of the plant the right of recourse to claim damage from Suppliers. This provision is a deviation from the international convention and did not sit well with suppliers, both domestic and foreign. Indian firms too exhibited reluctance to quote for the new PHWRs that were begun to be constructed. 
Table 5. Land requirement for Greenfield sites (data from the respective ElA reports).

\begin{tabular}{|c|c|c|c|c|c|}
\hline Site & Reactors (MWe) & Plant area (Ha) & $\mathrm{Ha} / \mathrm{MWe}$ & Township area (Ha) & $\mathrm{Ha} / \mathrm{MWe}$ \\
\hline Chutka & $2 \times 700$ & 430 & 0.30 & 68 & 0.050 \\
\hline Gorakhpur & $4 \times 700$ & 534 & 0.19 & 75 & 0.026 \\
\hline Kovvada & $6 \times 1200$ & $742^{\S \S}$ & 0.103 & 142 & 0.02 \\
\hline Jaitapur & $6 \times 1750$ & 692 & 0.066 & 246 & 0.023 \\
\hline
\end{tabular}

The Act does not define a Supplier. This is being addressed by explanations provided in the rules that, firms that fabricate components, according to designs provided to them, are not to be deemed as Suppliers. The fabricated components are further tested by the plant personnel before acceptance.

India ratified the IAEA Convention on Supplementary Compensation earlier this year to fall in line with International Practices. Besides, insurance arrangements have also been established to protect the Supplier.

\section{Public acceptance}

All countries that have nuclear plants have encountered some degree of public resistance to these plants being built close to human settlements. The basic concerns common to residents living near sites of major projects include threat of displacement, loss of livelihood, and perceived or actual threat from effluents. In the specific case of nuclear plants, there exist concerns of radiation hazards and nuclear accidents. These are magnified by those who tend to equate them with nuclear weapons. The very vivid images of the recent Fukushima accident tend to play on peoples' minds and outweigh any sound logic of reactor safety.

The initial years of the nuclear power program hardly witnessed any protests. However, a few years later, and especially after India's Pokhran nuclear test, there were allegations of an increase in radiation levels in these areas. There were also instances of adverse health impacts. However, absence of credible health data prior to plant operation led to mistaken identification of pre-existing conditions as caused by the reactors.

A highpoint of public protests regarding the proposed nuclear power station in Kaiga, Karnataka, was its location at the edge of a forest. It raised concerns that the radiation levels would destroy the forest. In this context, the State Government organised the first ever "public debate" attended by leading experts from the academia and research community. Following this, the project went ahead as per schedule.

The most recent example of protests against nuclear power stations is at the coastal site of Kudankulam, where four Russian design reactors are being built. After the agreement with the Soviet Union was signed in 1987, there were protests alleging that the Russian reactor's design was similar to that of Chernobyl. With the beginning of construction of the first reactor in
2002 , protests resumed and intensified in the aftermath of the Fukushima accident in 2011. Some leading bureaucrats and lawyers petitioned in the Supreme Court through a Public Interest Litigation. The reactor, though complete, could not commence operations for several months owing to these protests. The matter went up to the Supreme Court, which granted permission for loading fuel in May 2013.

The experience from various projects suggests that the objections tend to gradually cease once the plants begin generating. Improvements to the transport and communications infrastructure in the region along with job creation for the local population help to alleviate their concerns. One cause of irritation often is the fact that while the project township enjoys continuous supply of electricity, the neighboring village communities, which draw power from the State Electricity Board, experience frequent interruptions. This could be addressed through efforts to ensure tangible improvement in power supply to the neighboring villages.

Given India's ambitious nuclear power program, there is a need for a systematic and well-organised initiative for public acceptance. There is a need to undertake an exercise to assess the effectiveness and to draw lessons for improvement. Greater attention is required at the time of site evaluation to obviate delays once construction begins. It is best to take immediate note of the objections raised by the people, particularly those residing in the vicinity. There should be an attempt to provide answers even if the questions are based on unverified information, which is often the case. There is also a need for careful monitoring of media reports published in the local language. There is almost nothing that can be termed secret about a civilian nuclear program. There should be genuine transparency and honesty in addressing public concerns.

One way to ensure greater transparency and credibility is to delink the Regulatory Board from the Atomic Energy Commission to give a sense of independence to the Board. It might however take some time for the desired expertise and competence to develop outside the Department for providing technical support to the Board. A Bill for establishing a Nuclear Safety Regulatory Authority has been prepared and a Parliamentary Committee has discussed it, but it is yet to be presented in the Parliament. 


\section{Conclusion}

Nuclear power is a crucial component of India's energy policy. It is a source of clean baseload electricity. In recent years, India has provided impetus to nuclear power development. As part of its NDCs in the Paris COP, India reaffirmed its intention to develop 63,000 MW of nuclear power by 2030 .

In the near term (2030), India will continue its efforts to develop PHWRs and PWRs. This is essential for quick capacity addition and to address India's energy shortage. The NSG Waiver provides an opportunity for India to collaborate with international nuclear corporations and develop PWRs under safeguards.

India can also import natural and enriched uranium for operating the reactors. There are some reasons for continuing with the PHWRs, even as some PWRs are built, as India has a well-established supply chain in manufacture of PHWRs. However, the power rating of PHWRs will have to increase beyond $700 \mathrm{MW}$ so that there is more power from the same site. We estimate that by 2030 , India could potentially build about 30,000 MW of new nuclear reactors from a combination of PHWRs (11,200 MW), PWRs (17,800 MW), and FBR $(1,200)$ by expediting all efforts for regulatory clearances, funding action, stimulating support by industries, and gaining public acceptance. This will increase the installed capacity to 42,000 MW by 2030 .

In the long term (2050), India has plans to use its abundant thorium reserves. This will, however, require developing a reasonably large stockpile of plutonium, which will take time. Several options have been considered to explore early thorium utilisation. It is yet not clear which of these would be technically and commercially viable.

It is also important to set in process mechanisms to ensure public acceptance of nuclear power. One way to accomplish this is to have a strong and independent regulatory framework. This will help develop public confidence in the safety of design and operation of reactors. Public acceptance may turn out to be the limiting factor for the program.

\section{NOTES}

\footnotetext{
" Nuclear Power Corporation of India Ltd. (NPCIL) reports a present nuclear installed capacity of 5780 MW from 21 reactors. However, this includes Unit 1 of Rajasthan Atomic Power Station (100 MW), which has not been in operation since 2005 and it is unclear whether it would become operational. Therefore, we have excluded it from installed operational capacity. Also, the second VVER unit of $1000 \mathrm{MW}$ at Kudankulam is shortly expected to begin commercial operation. This will increase the operating capacity to $6680 \mathrm{MW}$.

$\dagger$ This assumes a load factor of $75 \%$ for nuclear and $20 \%$ for solar from a recent survey of 50 potential Indian sites. See http://www.cercind.gov.in/2011/ Whats-New/PERFORMANCE\%20OF\%20SOLAR\%20POWER\%20PLANTS.pdf. ` This includes 14 units of 220 MWe, two of 540 MWe and one of 200 MWe. $\S$ These are the forerunners of the 700 MWe units being standardised for the future.

** Grover (2016) mentioned 20 PHWRs. However, four PHWRs at Kakrapar and Rawatbhata are presently under construction and we have included these in Table 2. $\dagger^{\dagger}$ Grover (2016) mentioned 6 PWRs (1000 MW each) at Kudankulam. Out of these, one has been commissioned and three are under various stages of construction. We have included these in Tables 1 and 2.

Estimates based on the reactor thermal power, $75 \%$ capacity factor, reload enrichment and design burn-up level.
}

$\S \S$ In fresh acquisition the area acquired increased to a total of 840 ha for proposed AP1000 reactors. This is as per Rajya Sabha Question 404 answered on July $21,2016$.

\section{REFERENCES:}

1. Central Electricity Authority, Government of India: All India Installed Capacity-December 2016 (CEA, 2016). Available at: http://www.cea.nic. in/reports/monthly/installedcapacity/2016/installed_capacity-12.pdf (accessed 31 January 2017).

2. Ministry of Power, Government of India. Available at: http://powermin. nic.in/en/content/overview (accessed 27 October 2016).

3. Parliament of India, Lok Sabha: Unstarred Question 1300, answered on November 23, 2016. Available at: http://www.dae.nic.in/writereaddata/ parl/winter2016/lsus1300.pdf (accessed 31 January 2017).

4. International Energy Agency, IEA: Key World Energy Statistics (2016). Available at: http://www.iea.org/publications/freepublications/ publication/KeyWorld2016.pdf (accessed 31 January 2017).

5. Planning Commission, Government of India: Final Report of the Expert Group on Low Carbon Strategies for Inclusive Growth (Planning Commission, 2014). Available at: http://planningcommission.nic.in/ reports/genrep/rep_carbon2005.pdf (accessed 10 November 2016).

6. CSTEP: Quality of Life for All: A Sustainable Development Framework for India's Climate Policy (CSTEP, 2015). Available at: http://cstep.in/ uploads/default/files/publications/stuff/CSTEP_Quality_of_Life_for_ All_Report_2015.pdf (accessed 12 November 2016).

7. Ministry of Environment, Forests and Climate Change, Government of India: India's Intended Nationally Determined Contribution: Working towards Climate Justice (UNFCCC, 2015). Available at: http:// www4.unfecc.int/submissions/INDC/Published\%20Documents/ India/1/INDIA\%20INDC\%20TO\%20UNFCCC.pdf (accessed 29 October 2016).

8. Parliament of India, Rajya Sabha: Unstarred Question 1711, December 8, 2011. Available at: http://www.dae.nic.in/writereaddata/rsus1711_081211.pdf (accessed on 31 January 2017).

9. Livemint: PM Narendra Modi Wants Nuclear Power Capacity to be Tripled. Available at: http://www.livemint.com/Politics/ vqSkbdMVwYA2BqybcTmHIK/PM-Narendra-Modi-visits-BhabhaAtomic-Research-Centre.html (accessed 27 January 2017).

10. Department of Atomic Energy, Government of India: Three Stages of Indian Nuclear Power Programme. Available at: http://www.dae.nic. in/?q=node/212 (accessed 16 November 2016).

11. Department of Atomic Energy, Govt of India: Press Release 03/2012 dated April 20, 2012. Available at: http://dae.nic.in/writereaddata/ pr200412_0.pdf (accessed 24 November 2016).

12. Riyas A. and Mohanakrishnan P.: Studies on physics parameters of metal (U-Pu-Zr) fuelled FBR cores. Science 25, 50-51 (2007).

13. International Atomic Energy Agency (IAEA): INFCIRC/734-corrected, September 19, 2008. Available at: https://www.iaea.org/sites/default/ files/publications/documents/infcircs/2008/infcirc734c.pdf (accessed 26 January 2017).

14. Department of Atomic Energy, Government of India: Press Release on Programme of Action for Localisation of Manufacturing in India for Russiandesigned Nuclear Power Plants (Department of Atomic Energy, December 24, 2015). Available at: http://dae.nic.in/writereaddata/moscow24122015.pdf (accessed 26 November 2016).

15. Grover R.B.: The civil nuclear programme: The last decade and the outlook for the near future. Indian Foreign Aff. J. 10(3), 255-267 (2015).

16. Grover R.B.: Opening up of international civil nuclear cooperation with India and related developments. Progress in Nuclear Energy, In Press (September 29, 2016).

17. IAEA: Power Reactor Information System PRIS. Available at: https://www. iaea.org/PRIS/CountryStatistics/CountryStatisticsLandingPage.aspx (accessed 2 December 2016).

18. Puthiya Vinayagam P. and Chellapandi P.: Sustainable energy security from fast breeder reactors. Presented at the 6th Nuclear Energy Conclave, Energy Forum, New Delhi, India, 2014. Available at: http://docslide.net/ 
documents/p-puthiya-vinayagam-and-p-chellapandi-indira-gandhi-centrefor-atomic-research-568a65720cb75.html (accessed 6 December 2016).

19. Puthiyavinayagam P.: Progress in Fast Reactor Programme of India: April 2014-March 2015, 48th Annual Meeting of TWGFR (IAEA at IPPE, Obninsk, May 2015); pp. 25-29.

20. Umadevi K. and Sreekumar G.: Challenges in reprocessing of high burnup thermal reactor spent fuel. In Proceedings of the first DAE-BRNS symposium on recent advances in nuclear fuel cycle activities (IAEA - INIS, Tarapur, 2015).

21. Bhabha Atomic Research Centre: AHWR300-LEU: Advanced Heavy Water Reactor with LEU-Th MOX Fuel. Available at: http://dae.nic.in/ writereaddata/.pdf_31 (accessed 5 January 2017).

22. Banerjee S., Gupta H.P., and Bhardwaj S.A.: Nuclear power from thorium: Different options. Curr. Sci. 111, 1607-1623 (2016). Available at: http://www. currentscience.ac.in/Volumes/111/10/1607.pdf (accessed 25 November 2016).

23. Wattal P.K.: Recycling challenges of thorium-based fuels in thorium energy for the world. In Proceedings of the ThEC13 Conference, CERN (Globe of Science and Innovation, Geneva, Switzerland, October 27-31, 2013).

24. Parliament of India, Rajya Sabha: Unstarred Question 1864, (March 3, 2013). Available at: http://www.dae.nic.in/writereaddata/parl/bud2013/ rsus1864.pdf (accessed 29 January 2017).
25. Parliament of India, Rajya Sabha: Unstarred Question 481, December 3, 2015. Available at: http://www.dae.nic.in/writereaddata/parl/ winter2015/rsus481.pdf (accessed 29 January 2017).

26. Parliament of India, Lok Sabha: Unstarred Question 63, February 24, 2016. Available at: http://www.dae.nic.in/writereaddata/parl/ budget2016/lsus63.pdf (accessed 29 January 2017).

27. The Indian Express. Available at: http://indianexpress.com/article/india/ india-others/2-new-russian-reactors-for-kudankulam-to-cost-double-mostexpensive-n-plants/ (accessed 11 January 2017).

28. The Indian Express. Available at: http://indianexpress.com/article/ business/business-others/jaitapur-nuclear-project-renewed-push-amidlingering-concerns/ (accessed 30 January 2017).

29. Business Standard. Available at: http://www.business-standard.com/ article/economy-policy/we-are-confident-we-can-make-the-jaitapurproject-economically-viable-vakis-ramany-116112500027_1.html (accessed 26 November 2016).

30. Reuters cited in The Hindu Business Line. Available at: http://www.thehindubusinessline.com/economy/ indiauseximbankintalkson89bnnuclearloansnagsremain/ article9135103.ece (accessed 26 November 2016). 